\title{
Preliminary Design of Axial Flow Turbine for a Small Jet Engine
}

\author{
Ana A. G. Maia1, Janaina F. Silva², Jesuíno T. Tomita ${ }^{3}$, Cleverson Bringhenti ${ }^{4}$ \\ ${ }^{1}$ Aeronautics Institute of Technology \\ Pç. Mal. Eduardo Gomes, 50, São José dos Campos, Brazil \\ ana.adalgiza.eng@ hotmail.com; janaina@ita.br \\ ${ }^{2}$ Aeronautics Institute of Technology \\ Pç. Mal. Eduardo Gomes, 50, São José dos Campos, Brazil \\ jtakachi@ita.br; cleverson@ita.br
}

\begin{abstract}
A computational program used to calculate the preliminary design of axial turbines which uses the Kacker and Okapuu's loss model was modified to improve the losses predictions implementing Tournier and El-Genk's loss model. The in-house program was written in FORTRAN 90 and is based on the meanline technique to calculate the axial turbine. As the losses interfere in the geometrical calculations applying more accurate loss models, the predictions of the preliminary design are more reliable. The program was applied

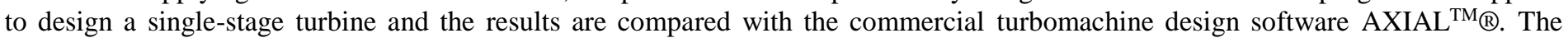
improvements obtained by applying a more recent loss model have been discussed as the future works to improve the in-house program.
\end{abstract}

Keywords: Gas turbines, Turbomachines, Preliminary design, Loss model.

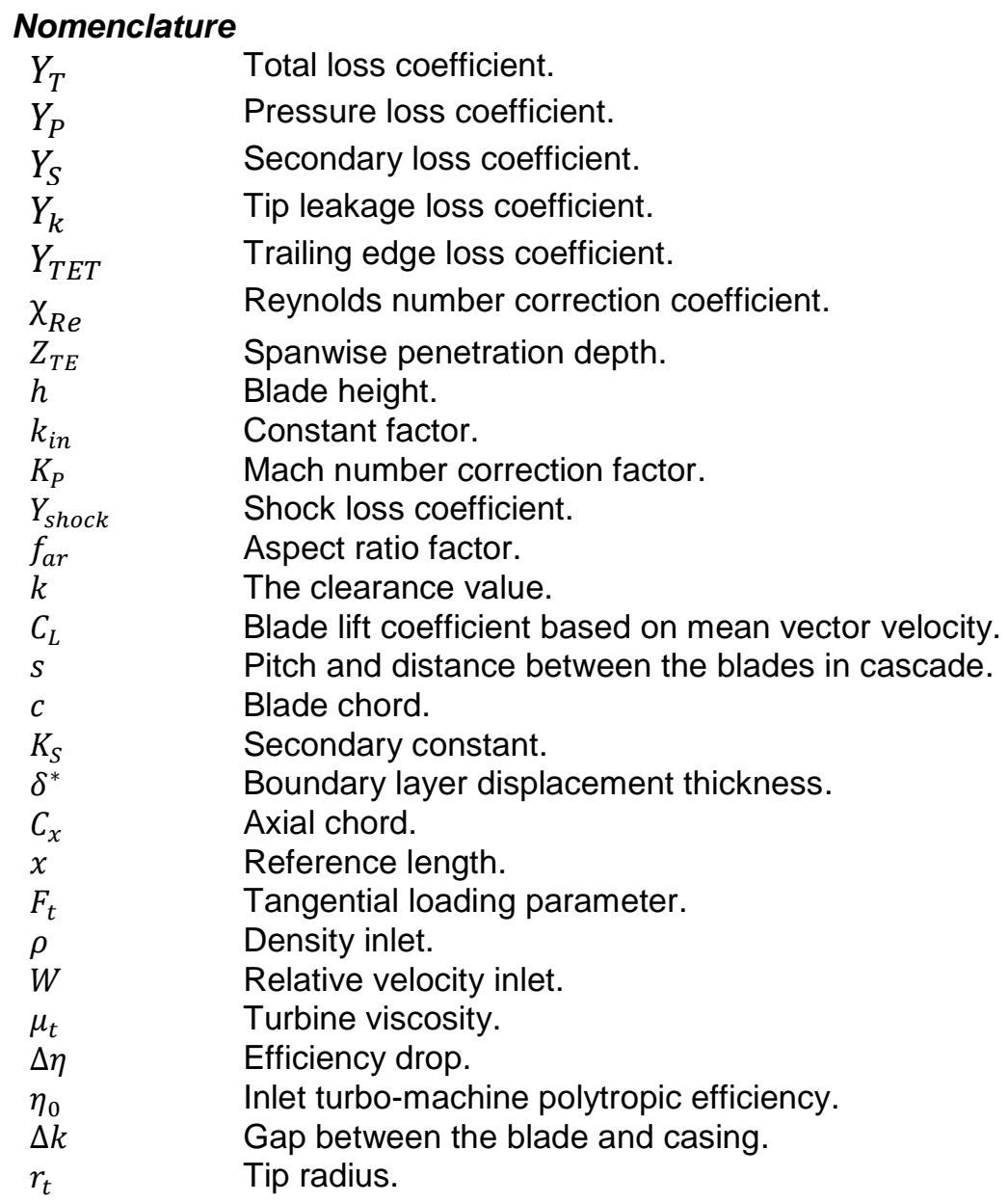




$\begin{array}{ll}r_{m} & \text { Averaged radius of the blade. } \\ \tau_{e f f} & \text { Effective clearance value. } \\ \alpha_{1} & \text { Inlet flow angle of the stator row. } \\ \alpha_{2} & \text { Inlet flow angle of the rotor row. } \\ \alpha_{3} & \text { Outlet flow angle of the rotor row. } \\ \alpha_{m} & \text { Mean flow angle between stator and rotor. } \\ K_{G}, K_{E}, & \text { Constants of Yaras and Slojander loss model. }\end{array}$

\section{Introduction}

Gas turbines engines has several components installed around it to provide thrust or power depending on its application, if aeronautical or industrial. The mechanical main components are compressor, combustion chamber and turbine and to increase the gas turbine design performance, improvements on these components are necessary. This involves a very high amount of investments over several multidisciplinary areas as computing, programming, math, physics, engineering, hardware, labs, tests, instrumentation, certification, high specialized labor of technicians, engineering and researchers. Generally, gas turbines are a subject of Defense Department of each country and there is no technological transfer due to the military aspect and sovereignty. This is the fact that a country, in which, wants to develop this world class technological product have to do the own investments starting with a high-end human resources formation.

Furthermore, manufacturing has the need to take into account the component tests, because it is common that several parts and components of gas turbines are designed and manufactured by the same company. This is due to the requirements of a very specific devices and mechanical pieces as bearings, seals, couplings and so on. Improvements on compressor and turbine designs are highly bound with engine enhancements. New engines depending on an aggressive investment in material technology involving super alloys and high temperature metals. Since the World War II for the actual days the development with these alloys increase the temperature ratio in approximately $14^{\circ} \mathrm{F}$ per year [1]. Therewith the engines core tends to be smaller and these changes are supported by high velocities, material strain and stresses. For aeronautical purposes, a lightweight and low power-to-thrust ratio are desired including acceptable specific fuel consumption. The new generation of engines must meet the requirements of noise and emissions [2] These topics are today the real challenges of gas turbine industry and involves many research centers, institutes and academic collaborations.

The development of losses models is done by several authors [3-5] in the last years. Ainley e Mathieson [6] made experiments and developed their correlations through experimental data results for axial flow turbines from blade design and measurement equipment for that time. This model has been used for many years and is the basis for many researches. The model has limitations as the flow Mach number, average Reynolds number, aspect ratio, and the ratio between trailing edge thickness and blade chord.

Later, Dunham and Came [7] made improvements in Ainley and Mathieson [6] model based on new tests for high velocity turbines. In this model, some loss sources were changed to validate its use for higher Mach number, influence of Reynolds number, improvements in tip losses and the possibility to apply the old model in turbine blades with low aspect ratios.

More changes in Ainley and Mathieson [6] and Dunham and Came [7] loss models are done by Kacker and Okapuu [8] where are restructured some loss sources, using the experimental data of 33 turbines (modern for the time). This model includes the compressibility effects and the losses generated from shock waves formation. The principal advantages of the Kacker and Okappu loss model [8] is the easy implementation in a current code as the quite approximate of the real axial turbine efficiency having a deviation of $1.5 \%$ more or less.

Moustapha et al [9], modified the profile and secondary losses to calculate the off-design conditions to adjust the earlier models to the new airfoils profiles. Looking to correct the predictions of the profile losses, Benner et al. [10] studied experimentally the low-speed cascade wind tunnel obtaining reliable predictions for this loss. More recently, Benner et al. $[11,12]$ proposed new correlations to evaluate the profile and secondary losses in turbines, creating the penetration depth correlation improving the predictions for the newest turbines. Tournier and El-Genk [13] developed a loss model which incorporates the refinements proposed by Benner et al. [11] in the Kacker and Okapuu loss model, also the authors suggested changes in the calculation of the tip clearance losses, showing accurate predictions to the geometrical parameters and losses for a most recent turbine design. 
In this work was applied a numerical in-house tool with is used to the preliminary turbine design to determine the geometrical parameters, the engine thermodynamic cycle calculations and the total losses. Basically, the code capabilities obtain reliable results to analyse a new turbine design. The computational code developed uses the Kacker and Okapuu loss model [8] and to improve the predictions of this model is implemented by the Tournier and El-Genk [13] loss model. Modular subroutines and easy handling of variables were structured into the code to facilitate its understanding and enhancements. The technique applied to the preliminary design of the turbomachine is the meanline. The turbine requirements, at the designpoint operation, were based on the work of Martins [14]. The simulation results will be compared with the results from a commercial turbomachines design software $\mathrm{AXIAL}^{\mathrm{TM}}{ }_{\circledR}$ analysing the losses and flow properties along the turbine stage.

\section{Methodology}

The total losses of the Kacker and Okapuu model [8] is expressed by Eq. (1):

$$
Y_{T}=\chi_{R e} Y_{P}+Y_{S}+Y_{k}+Y_{T E T}
$$

where, $Y_{t}$ is the total loss coefficient; $Y_{p}$ is the profile loss coefficient; $Y_{s}$ is the secondary loss coefficient; $Y_{k}$ is the tip leakage loss coefficient; $Y_{\text {tet }}$ is the trailing edge thickness coefficient and, $\chi_{R e}$ is the Reynolds number correction coefficient in [8].

Considering the Eq. (1) the authors incorporate more losses to refine the earlier models [6,7] improving the prediction of the losses to the preliminary design. In the passage of the flow in a row of blades, the profile losses are caused by the blade curvature, then the blade angles had an influence in this loss, additionally, the authors include the channel flow acceleration and the shock loss coefficient.

Secondary loss is caused by the formation of secondary flow along the blade passage due to the rotation of the blade rows generating a non-uniformity of the radial velocity [2], therefore these losses are dependent on the high velocities practised in axial turbines. The coefficient is calculated based on [8] and the function is changed to correct the aspect ratio for values less than two. Also, as the flow is accelerated between the blade endwall it is accounted for the compressibility effects in the loss model, for that is applied a Mach number correction factor.

When it is evaluated losses for high pressure turbines (HPT) the main responsibility for the pressure drop is for the tip clearance loss [8] which could be added to some models in the secondary losses. To improve the earlier models for unshrould blades, Kacker and Okapuu suggested an iterative process which is dependent on the efficiency drop calculated for the current model, obtaining values more accurate than in the AMDC model [6,7].

All in all, the model also separated the secondary losses in the trailing edge loss coefficient. This loss is defined as the function of the energy coefficient. The trailing edge loss is calculated considering the trailing edge thickness and the exit Mach number because the drag force is dependent on these values.

Tournier and El-Genk [13] proposed refinements in the Kacker and Okappu's model [8], then the total pressure loss coefficient is defined as,

$$
Y_{T}=\left(Y_{P}+Y_{S}\right)^{\prime}+Y_{T E T}+Y_{k}^{\prime}
$$

The model suggested to calculate the profile and secondary losses as one, where the spanwise penetration depth corresponds to the separation line between the primary and secondary loss regions [11]. The secondary loss coefficient (Ys) is changed by the authors to consider the boundary layer displacement thickness to calculate the formation of the secondary flow in the blade row. Also, Tournier and El-Genk [13] modified the tip clearance losses applying the approach of Yaras and Slojander [15] separating into tip and gap losses, for that, is considered the lift coefficient in the calculations.

Table 1 shows the losses changes in the model calculations between the Kacker and Okapuu's and Tournier and ElGenk [13]. Due to the limits established to the article size more details of the Kacker and Okapuu's and Tournier and ElGenk's loss models are encountered in references $[8,13]$. 
Table 1: Differences in the loss coefficients calculations for the Kacker and Okapuu [8] and Tournier and El-Genk [13].

\begin{tabular}{|c|c|c|}
\hline $\begin{array}{c}\text { Loss } \\
\text { Coefficients }\end{array}$ & Kacker and Okapuu & Tournier and El-Genk \\
\hline$\left(Y_{P}+Y_{S}\right)^{\prime}$ & $Y_{P}+Y_{S}$ & $\left(Y_{P}+Y_{S}\right)^{\prime}=\left(1-Z_{T E} / h\right)+Y_{P}{ }^{\prime}+Y_{S}^{\prime}$ \\
\hline$Y_{P}$ & $Y_{P}=0.914\left(k_{\text {in }} K_{P} Y_{P(i=0)}+Y_{\text {shock }}\right)$ & $Y_{P}=0.914\left(k_{\text {in }} K_{P} Y_{P(i=0)}+Y_{\text {shock }}\right)$ \\
\hline $\boldsymbol{k}_{\text {in }}$ & $2 / 3$ & $\begin{array}{c}0.825 \text { for IGV } \\
2 / 3 \text { for reaction blades }\end{array}$ \\
\hline$Y_{s}$ & $0.04008 f_{a r}\left(\frac{\cos \alpha_{2}}{\cos \alpha_{1}}\right)\left(\frac{C_{L}}{s / c}\right)^{2} \frac{\cos \alpha_{2}^{2}}{\cos \alpha_{m}^{2}} K_{S}$ & $f_{a r} \frac{0.038+0.41 \tanh \left(1.2 \delta^{*} / h\right)}{\sqrt{\cos \alpha_{m}}\left(\cos \alpha_{1} / \cos \alpha_{2}\right)\left(c \cos \alpha_{2} / C_{x}\right)^{0.55}}$ \\
\hline$Z_{T E} / h$ & & $\frac{0.1\left|F_{t}\right|^{0.79}}{\sqrt{\cos \alpha_{1} / \cos \alpha_{2}}(h / c)^{0.55}}+32.7\left(\frac{\delta^{*}}{h}\right)^{2}$ \\
\hline$F_{t}$ & & $2 \frac{s}{c \cos \alpha_{m}} \cos \alpha_{m}^{2}\left[\tan \left(\alpha_{1}\right)+\tan \left(\alpha_{2}\right)\right]$ \\
\hline$\delta^{*}$ & & $0.0463 x /\left(\rho_{1} W_{1} x / \mu_{t}\right)^{0.2}$ \\
\hline$f_{\text {ar }}$ & $\begin{array}{c}\left(1-0.25 \sqrt{2-\frac{h}{c}}\right) /(h / c) \text { for } h / c \leq 2 \\
(c / h) \text { for } h / c>2\end{array}$ & $\begin{array}{c}(c / h)^{0.55} \text { for } h / c \leq 2 \\
1.36604(c / h) \text { for } h / c>2\end{array}$ \\
\hline$Y_{k}^{\prime}$ & $\begin{array}{c}\frac{\Delta \eta}{\eta_{0}} / \frac{\Delta k}{h \cos \alpha_{2}} \frac{r_{t}}{r_{m}}=0.93 \text { for unshroud blades } \\
0.37 \frac{c}{h}\left(\frac{k^{\prime}}{c}\right)^{0.78}\left(\frac{C_{L}}{s / c}\right)^{2} \frac{\cos \alpha_{3}{ }^{2}}{\cos \alpha_{m}{ }^{3}} \text { for shroud blades }\end{array}$ & $Y_{T i p}+Y_{g a p}$ \\
\hline$Y_{\text {Tip }}$ & & $1.4 K_{e}\left(\frac{c}{S}\right) \frac{k}{h} \frac{\cos \alpha_{2}^{2}}{\cos \alpha_{m}{ }^{3}} C_{L}^{1.5}$ \\
\hline$Y_{\text {Gap }}$ & & $\begin{array}{c}0.0049 K_{G}\left(\frac{c}{S}\right) \frac{c}{h} \frac{\sqrt{C_{L}}}{\cos \alpha_{m}} \text { for unshroud blades } \\
1.102 K_{e}\left(\frac{c}{S}\right) \frac{\tau_{e f f}}{h} \frac{\cos \alpha_{2}^{2}}{\cos \alpha_{m}{ }^{3}} C_{L}^{1.5} \text { for shrould blades }\end{array}$ \\
\hline
\end{tabular}

\section{Axial Flow Turbine Parameters}

Table 1 shows the main data used in design-point turbine operation. Based on these requirements, the computational code will be handled to calculate the main machine characteristics.

Table 1: Axial turbine design data.

\begin{tabular}{|l|l|}
\hline Mass Flow $(\mathrm{kg} / \mathrm{s})$ & 7.952 \\
\hline Inlet Static Pressure $(\mathrm{kPa})$ & 476.277 \\
\hline Inlet Static Temperature $(\mathrm{K})$ & 1173.0 \\
\hline Drop in stage temperature $(\mathrm{K})$ & 172.28 \\
\hline Pressure ratio & 2.16 \\
\hline Rotation $(\mathrm{rpm})$ & 28150 \\
\hline Stator aspect ratio & 0.981 \\
\hline Rotor aspect ratio & 1.783 \\
\hline Power $(\mathrm{MW})$ & 1.722 \\
\hline Inlet flow angle (grades) & 0 \\
\hline Swirl angle (grades) & 61.75 \\
\hline
\end{tabular}


This turbine was designed using two different programs (commercial and in-house) and the results are compared. After several design parameters handling and modifications to reach the power, efficiency and pressure ratio the turbine geometry can be estimated. Fig. 1 shows the 3D view of the axial flow turbine calculated.

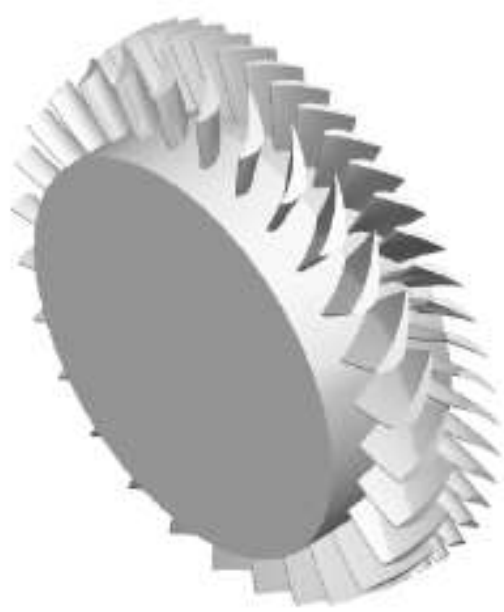

Fig. 1: Meridional section of axial turbine with one stage. Martins (2011).

The flowchart in Fig. 2 shows the procedure utilized in the program to calculate the turbine sizing from design requirements [16]. It was established as a design parameter that the turbine had a constant mean ratio for the stage. The flow, blade inlet and outlet angles are determined to make the use of loss modelling to improve the prediction of power and efficiency due to the losses quantification. Following to compare the preliminary design with the Martins work [14] the temperature drop is set as the same applied in the commercial software of AXIAL ${ }^{\mathrm{TM}}{ }$.

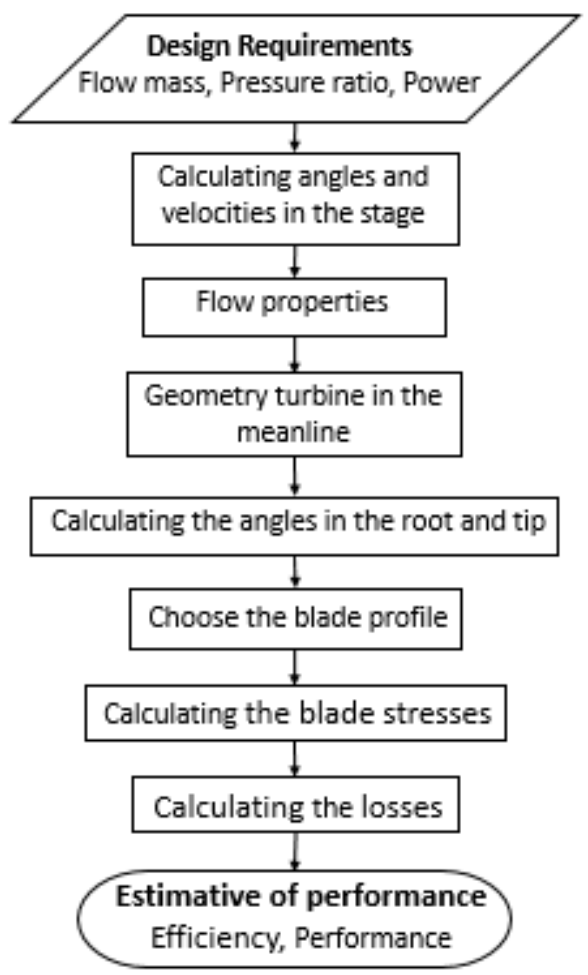

Fig. 2: Procedure for design and loss calculation. 


\section{Results and Discussion}

As explained in the above sections, after the implementation of the loss model of Tournier and El-Genk [13] in the inhouse program are set the design requirements shown in Table 1. The in-house program was applied to calculate the losses, properties and geometry of the preliminary design of an axial turbine for the Kacker and Okapuu and Tournier and El-Genk $[8,13]$ loss models. The results obtained with the in-house program were compared with the results obtained in [14] with the $\mathrm{AXIAL}^{\mathrm{TM}_{\circledast}}$ program.

\subsection{Losses coefficients}

The losses estimative is calculated to the in-house and to the commercial program. Table 2 showed the total losses calculated to the turbine stator and rotor rows.

Table 2: The design dates to the $\mathrm{AXIAL}^{\mathrm{TM}}{ }_{\circledast}$ and the program developed in-home.

\begin{tabular}{|c|l|c|c|c|}
\hline & & AXIAL $^{\mathrm{TM}}$ & Kacker and Okapuu & Tournier and El-Genk \\
\hline Total & Stator & 0.0767 & 0.0754 & 0.0489 \\
Losses & Rotor & 0.1492 & 0.213 & 0.117 \\
\hline
\end{tabular}

Analysing Table 1 is presented that the total stator losses demonstrated an underpredict to the in-house program in relation to the commercial program for both loss models, also the closest value is shown to the Kacker and Okapuu [8] loss model. In the rotor the total losses are overpredicted to the Kacker and Okapuu [8] loss model and is underpredicted to the Tournier and El-Genk [13] the last one is the closest value to the commercial program. Therefore, applying the Tournier and El-Genk [13] loss model in the in-house program, the rotor predictions are improved, which is responsible for the higherpressure losses.

Figs. 3 and 4 show the stator and rotor rows comparing the losses calculate for the Kacker and Okapuu [8] and Tournier and El-Genk [13].

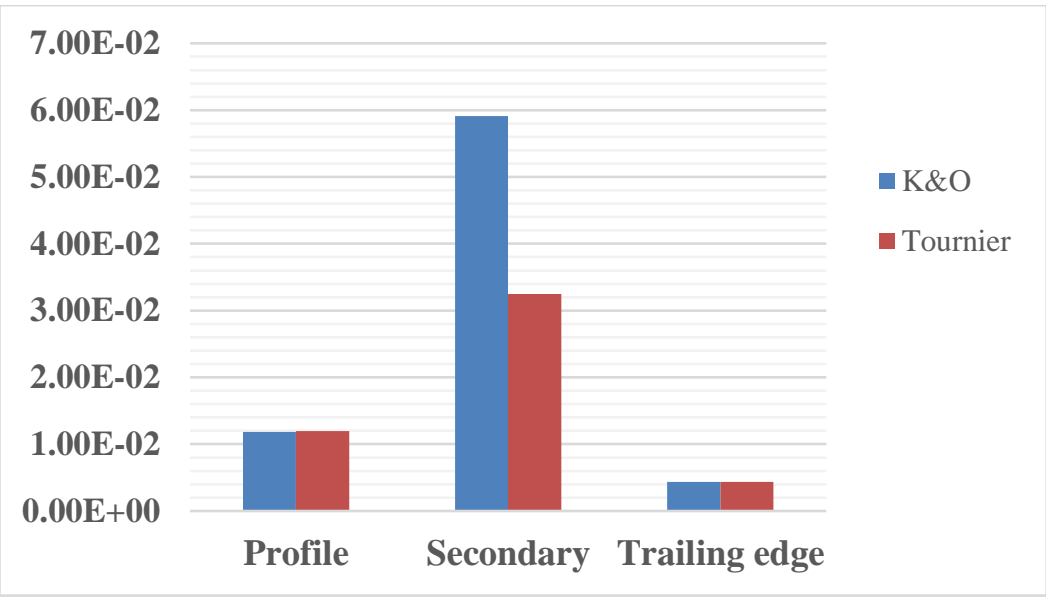

Fig. 3: Losses to the stator row for Kacker and Okapuu [8], Tournier and El-Genk[13] and AXIAL ${ }^{\mathrm{TM}}$. 


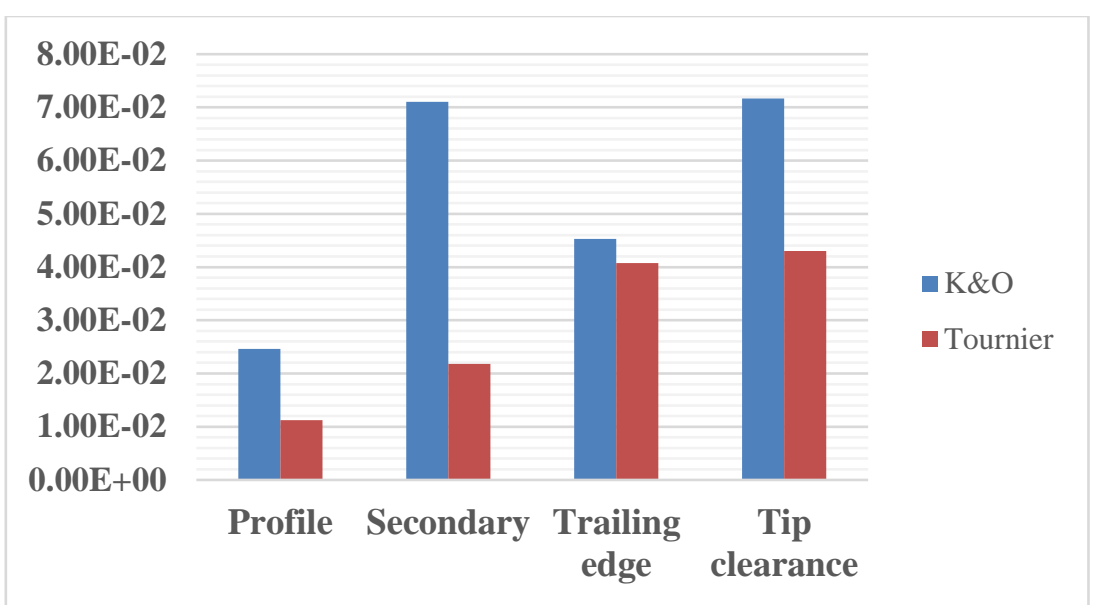

Fig. 4: Losses to the rotor row for Kacker and Okapuu [8], Tournier and El-Genk [13] and AXIAL $\mathbf{A M}_{\circledast \text {. }}$

Comparing the profile losses obtained to the models of Kacker and Okapuu [8] and Tournier and El-Genk [13] had a difference of $1 \%$ in the stator row due to the change in the factor of $2 / 3$ for a higher value to the IGV. Also, other factors are introduced by Tourner and El-Genk [13] as a factor to correct the flow Reynolds number as proposed by [15] and the spanwise penetration depth defined by [12], then the rotor profile loss had higher differences between the models indicating an overpredicted of the Kacker and Okapuu model.

For secondary losses the value of stator and rotor rows made a large difference between the models, indicating an overpredictment of the Kacker and Okapuu loss model [8]. It is expected differences due to the introduction of new corrections as the boundary layer displacement thickness and stagger angle, although the main differences occur because the Kacker and Okapuu model is based on the engines test and the Benner et al the corrections are based on the cascade tests. As a result, the Kacker and Okapuu's model overpredict the secondary losses and to improved that Benner et al.[12] suggested an engine-to-cascade correction factor improving the accuracy of the calculated and experimental data.

The trailing edge losses had closest values for both loss models because is not suggested changes to evaluate this loss. The tip clearance losses were estimated to the unshroud blades. The Kacker and Okapuu[8] loss model estimates this loss through an iterative method which related the turbine efficiency without the tip clearance loss and the total efficiency with the tip clearance loss. Next, the iterative process is done until the convergence and then the tip clearance loss is evaluated. Tourner and El-Genk[13] based the tip clearance loss on the work of Yaras and Sjolander[15] which consider the blade lift coefficient in their calculations. It is shown in Fig. 4 an overpredict of the tip clearance loss for the Kacker and Okapuu [8] loss model than to the losses calculated with the Tournier and El-Genk [13] model.

\subsection{Properties and Geometric Results}

In the Fig. 5 is shown a sketch of the turbine designed applying the in-house program.

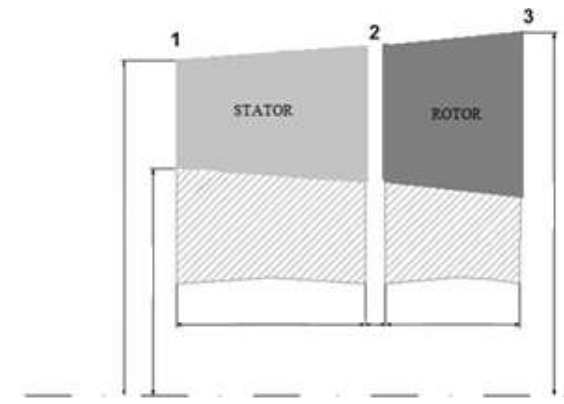

Fig. 5: Sketch of the turbine designed with the program developed in-house.

Table 3 presents the properties calculated for the in-house program and AXIAL program. The stations 1, 2 and 3 are located as shows in the Fig. 3. 
Table 3: The gas properties data to the $\mathrm{AXIAL}^{\mathrm{TM}}{ }_{\circledast}$ and the program developed in-house.

\begin{tabular}{|c|c|c|c|c|c|c|}
\hline & & AXIAL $^{\mathrm{TM}_{\circledast}}$ & $\begin{array}{c}\text { Kacker } \\
\text { and } \\
\text { Okapuu }\end{array}$ & & $\begin{array}{c}\text { Tournier } \\
\text { and El- } \\
\text { Genk }\end{array}$ & \\
\hline Properties & Station & Value & Value & $\begin{array}{l}\text { Percentage } \\
\text { error }\end{array}$ & Value & $\begin{array}{l}\text { Percentage } \\
\text { error }\end{array}$ \\
\hline $\begin{array}{l}\text { Total } \\
\text { pressure }\end{array}$ & $\begin{array}{l}1 \\
2 \\
3\end{array}$ & $\begin{array}{l}476227 \\
467109 \\
220596\end{array}$ & $\begin{array}{l}476227 \\
468397.55 \\
204890.36\end{array}$ & $\begin{array}{l}- \\
0.276 \% \\
-7.12 \%\end{array}$ & $\begin{array}{l}476227 \\
470329.71 \\
217960.458\end{array}$ & $\begin{array}{l}- \\
0.689 \% \\
-1.195 \%\end{array}$ \\
\hline $\begin{array}{l}\text { Relative } \\
\text { pressure }\end{array}$ & $\begin{array}{l}1 \\
2 \\
3\end{array}$ & $\begin{array}{l}- \\
379479 \\
348398\end{array}$ & $\begin{array}{l}- \\
379424.11 \\
320341.91\end{array}$ & $\begin{array}{l}- \\
-0.014 \% \\
-8.05 \%\end{array}$ & $\begin{array}{l}- \\
381173.68 \\
340776.75\end{array}$ & $\begin{array}{l}- \\
0.447 \% \\
-2.188 \%\end{array}$ \\
\hline $\begin{array}{l}\text { Static } \\
\text { pressure }\end{array}$ & $\begin{array}{l}1 \\
2 \\
3\end{array}$ & $\begin{array}{l}438894 \\
348199 \\
164215\end{array}$ & $\begin{array}{l}438894 \\
348207.995 \\
15294.904\end{array}$ & $\begin{array}{l}- \\
0.003 \% \\
-6.954 \%\end{array}$ & $\begin{array}{l}438894 \\
349813.62 \\
162541.80\end{array}$ & $\begin{array}{l}- \\
0.464 \% \\
-1.019 \%\end{array}$ \\
\hline Density & $\begin{array}{l}1 \\
2 \\
3\end{array}$ & $\begin{array}{l}1.288666 \\
1.074439 \\
0.595291\end{array}$ & $\begin{array}{l}1.288666 \\
1.067956 \\
0.550533\end{array}$ & $\begin{array}{l}-0.603 \% \\
7.519 \%\end{array}$ & $\begin{array}{l}1.288666 \\
1.072880 \\
0.585652\end{array}$ & $\begin{array}{l}-145 \% \\
-1.619 \%\end{array}$ \\
\hline
\end{tabular}

The properties calculated by the in-house program applying the Kacker and Okapuu[8] and Tournier and El-Genk [13] loss models are compared with the values obtained by the $\mathrm{AXIAL}^{\mathrm{TM}}{ }_{\circledast}$ program in the work developed by [martins] demonstrating differences lower than $9 \%$ for the Kacker and Okapuu model and lower than 2.5\% for the Tournier model. All in all, applying the Tournier model the properties predictions are improved.

Table 4 presents the geometric parameters calculated to the developed in-house program and to the $\mathrm{AXIAL}^{\mathrm{TM}_{\mathbb{B}}}$ program.

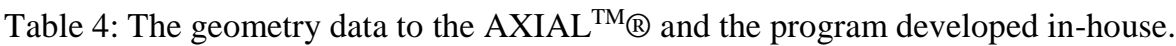

\begin{tabular}{|c|c|c|c|c|c|c|}
\hline & & AXIAL $^{\mathrm{TM}_{\circledast}}$ & $\begin{array}{l}\text { Kacker and } \\
\text { Okapuu }\end{array}$ & & $\begin{array}{c}\text { Tournier and } \\
\text { El-Genk }\end{array}$ & \\
\hline Geometry & Station & Value & Value & $\begin{array}{c}\text { Percentage } \\
\text { error }\end{array}$ & Value & $\begin{array}{c}\text { Percentage } \\
\text { error }\end{array}$ \\
\hline $\begin{array}{c}\text { Annulus } \\
\text { area }\end{array}$ & $\begin{array}{l}1 \\
2 \\
3 \\
\end{array}$ & $\begin{array}{l}2.6044 \mathrm{E}-02 \\
3.1530 \mathrm{E}-02 \\
3.7598 \mathrm{E}-02\end{array}$ & $\begin{array}{l}2.60 \mathrm{E}-02 \\
3.14 \mathrm{E}-02 \\
3.99 \mathrm{E}-02 \\
\end{array}$ & $\begin{array}{l}-0.0001 \% \\
-0.4429 \% \\
6.1589 \% \\
\end{array}$ & $\begin{array}{l}2.6044 \mathrm{E}-02 \\
3.1246 \mathrm{E}-02 \\
3.7520 \mathrm{E}-02 \\
\end{array}$ & $\begin{array}{l}-0.0001 \% \\
-0.8998 \% \\
-0.207 \%\end{array}$ \\
\hline $\begin{array}{c}\text { Throat } \\
\text { area }\end{array}$ & $\begin{array}{l}1 \\
2 \\
\end{array}$ & $\begin{array}{l}1.6367 \mathrm{E}-02 \\
1.8535 \mathrm{E}-02 \\
\end{array}$ & $\begin{array}{l}1.68 \mathrm{E}-02 \\
1.01 \mathrm{E}-02 \\
\end{array}$ & $\begin{array}{l}2.4671 \% \\
-45.3332 \% \\
\end{array}$ & $\begin{array}{l}1.6694 \mathrm{E}-02 \\
1.0086 \mathrm{E}-02 \\
\end{array}$ & $\begin{array}{l}1.997 \% \\
-45.584 \% \\
\end{array}$ \\
\hline $\begin{array}{l}\text { Blade } \\
\text { height }\end{array}$ & $\begin{array}{l}1 \\
2 \\
3 \\
\end{array}$ & $\begin{array}{l}3.2844 \mathrm{E}-02 \\
3.8744 \mathrm{E}-02 \\
4.7963 \mathrm{E}-02 \\
\end{array}$ & $\begin{array}{l}3.19 \mathrm{E}-02 \\
3.85 \mathrm{E}-02 \\
4.90 \mathrm{E}-02 \\
\end{array}$ & $\begin{array}{l}-2.8174 \% \\
-0.7047 \% \\
2.1664 \% \\
\end{array}$ & $\begin{array}{l}.1919 \mathrm{E}-02 \\
3.8294 \mathrm{E}-02 \\
4.6004 \mathrm{E}-02 \\
\end{array}$ & $\begin{array}{l}-2.817 \% \\
-1.160 \% \\
-4.085 \% \\
\end{array}$ \\
\hline $\begin{array}{l}\text { Stagger } \\
\text { angle }\end{array}$ & $\begin{array}{l}1 \\
2\end{array}$ & $\begin{array}{l}37.6298 \\
34.6233\end{array}$ & $\begin{array}{l}39.0836 \\
36.3292\end{array}$ & $\begin{array}{l}3.8635 \% \\
4.9271 \%\end{array}$ & $\begin{array}{l}39.0840 \\
36.4120\end{array}$ & $\begin{array}{l}3.865 \% \\
5.166 \%\end{array}$ \\
\hline Chord & $\begin{array}{l}1 \\
2\end{array}$ & $\begin{array}{l}3.95 \mathrm{E}-2 \\
2.69 \mathrm{E}-2\end{array}$ & $\begin{array}{l}4.30 \mathrm{E}-2 \\
2.50 \mathrm{E}-2\end{array}$ & $\begin{array}{l}8.7718 \% \\
-7.2409 \%\end{array}$ & $\begin{array}{l}4.296 \mathrm{E}-2 \\
2.495 \mathrm{E}-2\end{array}$ & $\begin{array}{l}8.772 \% \\
-7.241 \%\end{array}$ \\
\hline Axial chord & $\begin{array}{l}1 \\
2\end{array}$ & $\begin{array}{l}3.1283 \mathrm{E}-02 \\
2.2136 \mathrm{E}-02\end{array}$ & $\begin{array}{l}3.34 \mathrm{E}-02 \\
2.01 \mathrm{E}-02\end{array}$ & $\begin{array}{l}6.6092 \% \\
-9.1884 \%\end{array}$ & $\begin{array}{l}3.3350 \mathrm{E}-02 \\
2.0081 \mathrm{E}-02\end{array}$ & $\begin{array}{l}6.609 \% \\
-9.285 \%\end{array}$ \\
\hline $\begin{array}{l}\text { Aspect } \\
\text { ratio }\end{array}$ & $\begin{array}{l}1 \\
2 \\
\end{array}$ & $\begin{array}{l}0.9809 \\
1.7830 \\
\end{array}$ & $\begin{array}{l}0.81915 \\
1.73277 \\
\end{array}$ & $\begin{array}{l}-16.36 \% \\
-2.07 \% \\
\end{array}$ & $\begin{array}{l}0.8171 \\
1.6691 \\
\end{array}$ & $\begin{array}{l}-16.70 \% \\
-6.41 \% \\
\end{array}$ \\
\hline
\end{tabular}


The higher differences in the geometrical calculations are found in the throat area to the rotor row. The discrepancies are due to the differences in the turbine design because the $\mathrm{AXIAL}^{\mathrm{TM}}{ }_{\circledast}$ program considered for each stage the enthalpy constant and to the in-house program is considered the axial velocity constant in each station.

\section{Conclusion}

The program developed in this work has the capability to help engineers design axial flow turbines without cooling, using the main data from engine thermodynamic cycle calculation. Initially, the in-house program was implemented by the Kacker and Okapuu [8] loss model. Looking to improve the losses predictions is implemented a more recent work by Tournier and El-Genk [13]. The results obtained for the total losses showed improvements in the rotor predictions. The results found that the preliminary turbine design increases the accuracy to predict the flow properties. Although the geometry calculated to the in-house program had some discrepancies due to different design criteria. The algorithm created allows the implementation of other loss models due to the modular structure.

In future works, the implementation of other design criteria and optimization techniques will be improve the predictions to the in-house program.

\section{Acknowledgements}

The authors would like to thank Fapesp (Fundação de Apoio à Pesquisa do Estado de São Paulo), CNPq (Conselho Nacional de Desenvolvimento Científico e Tecnológico), CAPES (Coordenação do Aperfeiçoamento do Pessoal de Nível Superior) and the Turbomachines Department at ITA to support this work.

\section{References}

[1] W. W. Bathie, Fundamentals of Gas Turbines. John Wiley and Sons, Inc., New York, NY, 1996.

[2] H. I. H Saravanamutto, G. F. C. Rogers, H. Cohen, P. V. Stranznicky, Gas Turbine Theory. Ed. Prantice and Hall, London, 2009.

[3] O. E. Baljé and R. L. Binsley, "Axial Turbine Performance Evaluation. Part A - Loss-Geometry Relationship,” ASME Journal of Engineering for Power, pp. 341-348, 1968.

[4] H. R. M. Craig and H. J. A. Cox, "Performance Estimate of Axial Flow Turbines," Proceedings of the Institution of Mechanical Engineers, vol. 185, no. 32, pp. 407-424, 1970.

[5] W. Traupel, "Thermische Turbomaschinen Zweiter Band Geänderte Betriebsbedingungen, Regelung, Mechanische Probleme, Temperaturprobleme.” Springer-Verlag Berlin Heidelberg, New York, 1977.

[6] D. G. Ainley and G. C. R. Mathieson, "A method of performance estimation for axial-flow turbines," Aeronautical Research Council Report and Memoranda, R\&M 2874, 1951.

[7] J. Dunham and P. M. Came, "Improvements to the Ainley/Mathieson method of turbine performance," ASME Journal of Engineering for Power, vol. 92, no.3, pp. 111-119, 1970.

[8] S. C. Kacker and U. Okapuu, "A Mean Line Prediction Method for Axial Flow Turbine Efficiency," ASME Journal of Engineering for Power, vol. 104, pp. 111-119, 1982.

[9] S. H. Moustapha, S. C. Kacker, B. Tremblay, "An Improved Incidence Losses Prediction Method for Turbine Airfoils,".ASME Journal of Engineering for Power, vol. 89, GT-284, pp. 267-276, 1990.

[10] M. W. Benner, S. A. Slojander, S. H. Moustapha, "Influence of Leading-edge Geometry on Profile Losses in Turbines at Off-Design Incidence: Experimental Results and an Improved Correlation," ASME J. of Turbomach., vol. 199, pp. 193-200, 1997.

[11] M. W. Benner, S. A. Slojander, S. H. Moustapha, "An Empirical Prediction Method for Secondary Losses in Turbines: Part I," ASME J. of Turbomach., vol. 128, 2006.

[12] M. W. Benner, S. A. Slojander, S. H. Moustapha, "An Empirical Prediction Method for Secondary Losses in Turbines: Part II," ASME J. of Turbomach., vol. 128, 2006.

[13] J. M. Tournier and M. S. El-Genk, "Axial Flow, Multi-stage Turbine and Compressor Blades," Energy Conversion and Management, vol. 51, pp. 16-29, 2010.

[14] V. A. C. Martins, "Projeto Preliminar de uma Turbina Axial para uso em Turbina a Gás de Pequena Potência," Trabalho de Graduação, Instituto Tecnológico de Aeronáutica, São José dos Campos, S. P., Brazil, p. 84, 2011. 
[15] M. I. Yaras and S. A. Sjolander, "Prediction of Tip-leakage Losses in Axial Turbines," J. of Turbomach., vol. 114, no. 204, 1992.

[16] A. A. G. Maia, J. F. Silva, J. T. Tomita and C. Bringhenti, "Development of a Numerical Tool for Preliminary Sizing of Axial Turbines," in 22 ${ }^{\text {nd }}$ International Congress of Mechanical Engineering (COBEM), Ribeirão Preto, SP, 2013, pp. 9731-9738. 